\title{
Visibility and Fog Drop Size Spectra at Misawa Air Base
}

\author{
Tomohiro OKUDA, Kikuro TOMINE, Fumiaki KOBAYASHI, \\ and \\ Hirofumi SUGAWARA \\ Institute of Earth and Ocean Sciences, National Defense Academy, Kanagawa, Japan
}

(Manuscript received 2 November 2007, in final form 30 July 2008)

\begin{abstract}
Size spectra of fog drops are investigated at Misawa Air Base to determine which sizes of drops are mainly responsible for degrading visibility in fogs. It is found fog drops smaller than $5 \mu \mathrm{m}$ in diameter contribute less than $2 \%$ to the extinction coefficient. Degraded visibility is caused by smaller fog drops than $60 \mu \mathrm{m}$ under thinner fog layers than $130 \mathrm{~m}$ in this study. Drop size distributions spread and the representative drop size for degrading visibility increases with fog thickness under fog layers thicker than $280 \mathrm{~m}$. So, not only the maximum drop size increases with fog thickness but also the influences of large drops on the extinction coefficient in fogs increase with fog thickness. For evolutions of visibility, increase of small drops is important for rapid degrading visibility irrespective of fog thickness and increase of large drops corresponds to slow changes of visibility under thick fogs.
\end{abstract}

\section{Introduction}

Fogs or obscuration visibility interrupt airport operations frequently near the Pacific Ocean in northern Japan in summer. Visibility in a fog is related to droplet size spectra, and these spectra are thus important for understanding fog formation.

Cloud drops have been studied more frequently than fog drops. Squires et al. (1958) measured cloud droplet spectra in various types of clouds using a technique where droplets are collected on a layer of magnesium oxide. They found narrow spectra and droplet sizes smaller than $20 \mu \mathrm{m}$ in warm continental cumuli. They observed large size drops of $160 \mu \mathrm{m}$ in diameter in orographic clouds over Hawaii. Recently, vertical profiles of cloud droplet size spectra were measured using in-

Corresponding author: Kikuro Tomine, Institute of Earth and Ocean Sciences, National Defense Academy, 1-10-20, Hashirimizu, Kanagawa, 239-8686, Japan.

E-mail: tomine@nda.ac.jp

(C)2008, Meteorological Society of Japan strumented aircrafts and tethered balloons (Slingo et al. 1982; Nicholls 1984). These studies found droplet size spectra of less than $30 \mu \mathrm{m}$ in diameter. Duynkerke et al. (1999) measured cloud drop sizes from 1 to $300 \mu \mathrm{m}$ using a forward scattering spectrometer probe (FSSP) and two-dimensional cloud probe (2DC). They showed the relative contribution made by different sized droplets to the total liquid water content in a nocturnal stratocumulus layer, and found that droplets smaller than $30 \mu \mathrm{m}$ in diameter contributed most to the liquid water content. Brenguier et al. (2000) observed profiles of mean volume diameter in stratocumuli.

Homma et al. (1962) sampled fog and drizzle droplets to know relations between the drizzle droplets size and the fog thickness. They showed that drizzle fell from the fog layer thicker than 400 $\mathrm{m}$ but sometimes no drizzle fell from even such thick fog layer. Drop size spectra in fogs were, also, measured by Pilié et al. (1975). They observed only drops smaller than $26 \mu \mathrm{m}$ in diameter in ground fogs and drops smaller than $56 \mu \mathrm{m}$ in mature fogs. Mason (1982) introduced fog droplets smaller than 
$36 \mu \mathrm{m}$ in diameter. Vertical profiles of fog droplets size and water content were measured with a large tethered balloon by UMIGIRI KENKYUU GROUP (1985). They observed two zones of maximum water content, one near the ground surface and another several hundred meters above ground level. Observations of fog droplets over the sea showed that the droplet size had a tendency to be less than that near the surface, and the number density of each droplet size changed in similar manner. Kaband radar echoes (wavelength: $8.6 \mathrm{~mm}$ ) showed two types of fogs, one that was stationary near the coast and another that was moving onshore. Yanagisawa et al. (1986) investigated relations between Ka-band radar reflectivity and visibility. They found one case where visibility was short in strong radar reflectivity, and another case with long visibility in strong radar reflectivity. In the former case, the fog was formed of small droplets, and in the latter case it included many large droplets. They also found that smaller drops than $50 \mu \mathrm{m}$ in diameter were prevailing in fogs which radar echo heights were lower than $400 \mathrm{~m}$ and drops of $80 \mu \mathrm{m}$ diameter or larger than that were observed in fogs with high echo top of $1200 \mathrm{~m}$.

Inoue (1992) investigated differences between fogs composed primarily of small droplets and those that included many large droplets. Haraoka et al. (1995) summarized characteristics of vertical profiles of atmospheric temperature, relative humidity, wind direction, and wind speed in sea fogs. They also separated fogs into two types. One type was a thin fog layer under a low temperature inversion layer, which easily dissipated in the morning; the other type was a thick humid layer under a widespread stratus, which was not easy to dissipate. Fogs in the area of this study could be separated into the two types described above, one formed mainly of relatively small droplets and the other including many large droplets.

Many studies have investigated the role of cloud or fog droplets in degrading visibility. Visibility degradation can be calculated from drop size spectrum following aufm Kampe and Weickmann (1952). But very few studies have calculated visibility from drop size spectra, and thus it is not known which size of drops is mainly responsible for the degradation of visibility in fogs. This information is necessary for understanding the mechanisms of visibility degradation. A problem for the investigation of droplet sizes responsible for degradation of visibility in fogs is that fog droplet size spectra are not measured in routine observations (such as those observation at the Misawa Air Base). For this study, the fog droplet size spectrum was observed at the air base as part of the investigation of visibility degrading mechanisms.

\section{Observational area and methods}

The sea fog observations were performed near the weather station in Misawa Air Base in the Aomori prefecture, from 20 June to 10 July, 2005. Misawa Air Base is $39 \mathrm{~m}$ above the sea level and about $5 \mathrm{~km}$ inland from the coast of the western Pacific Ocean. Lake Ogawara and Ane pond are north of the air base (see Fig. 1). This region is famous in Japan for its frequent sea fogs.

RAWIN sondes (Vaisala, RS-80) were launched near the observation site. When the visibility was greater than $1600 \mathrm{~m}$, we used the prevailing visibility reported by observers in the base. When visibility was shorter than $1600 \mathrm{~m}$, we used observations with a transmissometer situated near the runway about $1 \mathrm{~km}$ away from the site. A particle counter (RION KC01E) was used for observation of droplets smaller than $5 \mu \mathrm{m}$ in diameter. The counter records concentration of particles larger than $0.3 \mu \mathrm{m}, 0.5 \mu \mathrm{m}, 1 \mu \mathrm{m}, 2 \mu \mathrm{m}$, and $5 \mu \mathrm{m}$ in diameter. The concentration of each size of droplets is calculated as the difference between the two neighboring records. Larger falling fog droplets could be observed as they left craters on a glass slide coated by a layer of magnesium oxide (Maruyama and Hama 1954). In this method however, droplets smaller than $10 \mu \mathrm{m}$ in diameter are difficult to distinguish from dust, and droplets larger than 200 $\mu \mathrm{m}$ leave deformed craters on the magnesium oxide layer. Thus in this study, we were only able to analyze droplets from $10 \mu \mathrm{m}$ to $200 \mu \mathrm{m}$, and could only show the existence of drizzle when droplets larger than $200 \mu \mathrm{m}$ were observed. This method is more troublesome than a particle counter measurement, and prone to include errors related to wind direction. However we still use the method because most particle counters are not able to measure particles larger than $50 \mu \mathrm{m}$, and sea fogs often include droplets larger than this diameter.

A fog droplet diameter is calculated from the crater diameter as following:

$$
\mathrm{D}=0.788 \times \mathrm{d} .
$$

Where $\mathrm{D}$ and $\mathrm{d}$ are the diameters of the droplet and the crater, respectively. The correction coefficient 0.788 is following Maruyama and Hama 

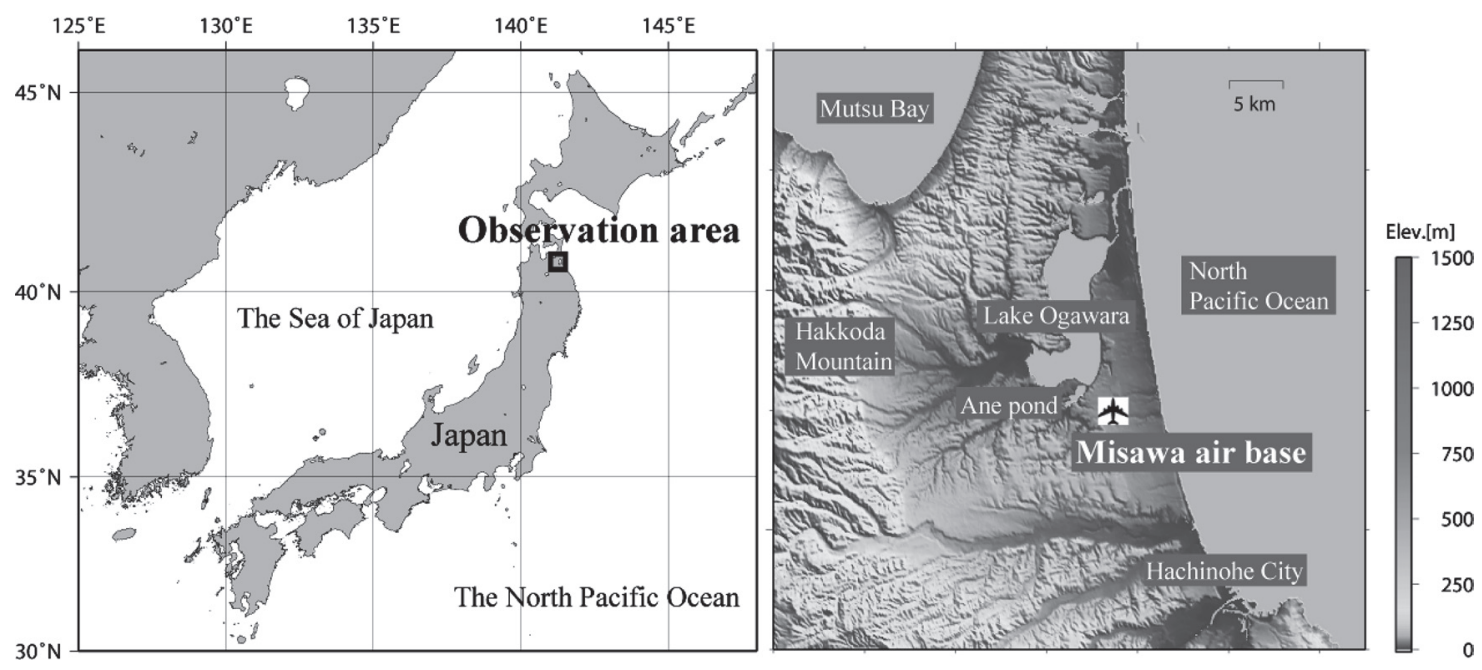

Fig. 1. Maps of the observational area (left) and Misawa Air Base (right).

(1954). Number density of fog droplets is calculated as follows:

$$
N=\frac{n}{s \times v \times t} .
$$

Where $N, n, s, v$, and $t$ are the number density, the number of craters, the investigated area, the terminal velocity of fog droplets, and the exposure time of the slide glass, respectively.

The equation (2) assumes that the fog droplets keep the terminal fall speed. We wondered, however, whether the droplets actually fell at the terminal fall speed when driven by winds. So the data obtained through this method were compared with the data obtained from a particle counter of which range was from 2 to $50 \mu \mathrm{m}$ for a case. The results calculated from the crater numbers were 1.2 times larger than that of the particle counter for droplets of $15 \mu \mathrm{m}$ in diameter, although it was 1.7 times larger than that for droplets of $45 \mu \mathrm{m}$ in diameter.

\section{A case on 20 and 21 June}

\subsection{Upper air soundings}

Vertical profiles of relative humidity, potential temperature, equivalent potential temperature, and specific humidity in a fog during the night of 20 June are shown in Fig. 2. The fog tops heights are estimated to be the height of the maximum relative humidity. The fog top height was about $280 \mathrm{~m}$ at 21:00 JST and it was the highest during the night. Vertical profiles of potential temperature and specific humidity show non-uniform air in the fog layer at 21:00 JST. The fog top height dropped to $130 \mathrm{~m}$ at 00:00 JST on the $21^{\text {st }}$, remained at $110 \mathrm{~m}$ at 03:00 JST, and dropped further to $70 \mathrm{~m}$ at 06:00 JST. The vertical profiles of potential temperature and specific humidity show that the fog layer consists of well-mixed air after 00:00 JST. It is known that a well-mixed internal boundary layer, approximately $100 \mathrm{~m}$ thick, is formed when air flows out from a warm land surface towards a colder water surface (Smedman et al. 1997).

\subsection{Visibility and other meteorological elements}

Visibility and surface wind at the air base are shown in Fig. 3 for a fog observed from 16:52 JST on 20 June to 06:07 JST on 21 June. Visibility was a minimum of $500 \mathrm{~m}$ at 20:00 JST and improves to $800 \mathrm{~m}$ at $21: 00$ and 22:00 JST on 20 June. It decreased rapidly to $400 \mathrm{~m}$ at 23:00 JST, as the wind direction changes from easterly (onshore wind) to westerly (offshore wind). It remained under $400 \mathrm{~m}$ until 04:41 JST on 21 June. The minimum visibilities were observed at 20:00 (500 m), 00:01 $(200 \mathrm{~m})$, 02:55 (200 m), and 04:55 JST (300 m). Wind speed was approximately $2 \sim 2.5 \mathrm{~m} \mathrm{~s}^{-1}$ before the wind direction changed at 22:24 JST. It decreased gradually from $1.5 \mathrm{~m} \mathrm{~s}^{-1}$ at 01:00 JST to $0.2 \mathrm{~m} \mathrm{~s}^{-1}$ at $05: 00$ JST. Fog droplet size spectra are shown in Figs. 4a and b. Droplet concentrations smaller than $1 \mu \mathrm{m}$ did not correspond to changes of visibility. Droplet concentrations between 1 and $2 \mu \mathrm{m}$ and between 2 and $5 \mu \mathrm{m}$ were 0.7 and $0.07 \mathrm{~cm}^{-3} \mu \mathrm{m}^{-1}$, respectively, at 19:00 JST, and they increased slowly until 21:00 
(a) 21:00JST on 20 June Potential Temperature $[\mathrm{K}] \quad$ Specific Humidity $\left[\mathrm{g} \mathrm{kg}^{-1}\right]$

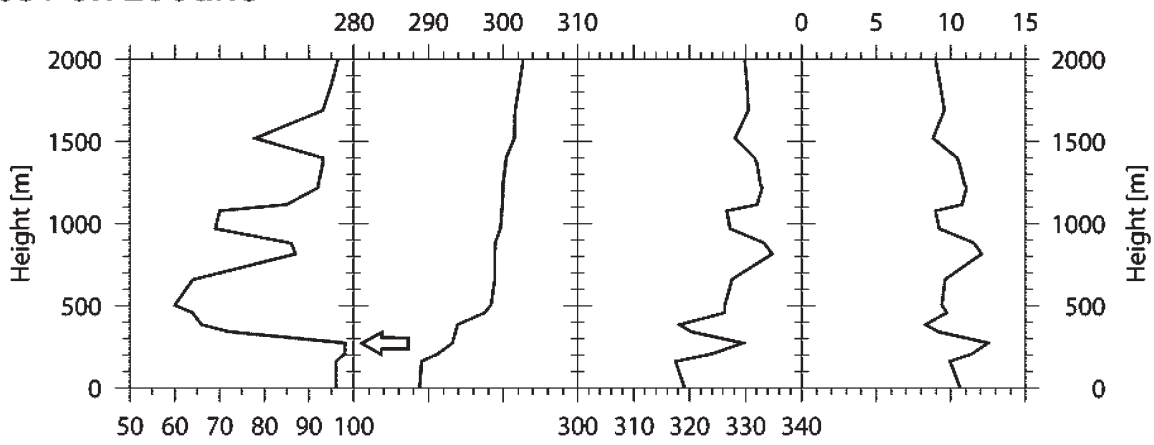

(b) 00:00JST on 21 June

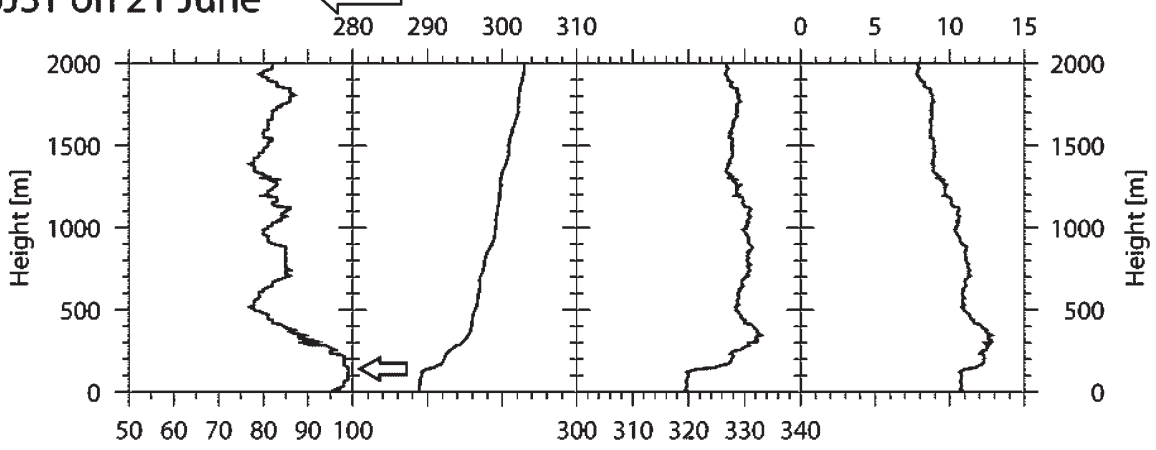

(c) 03:00JST on 21 June

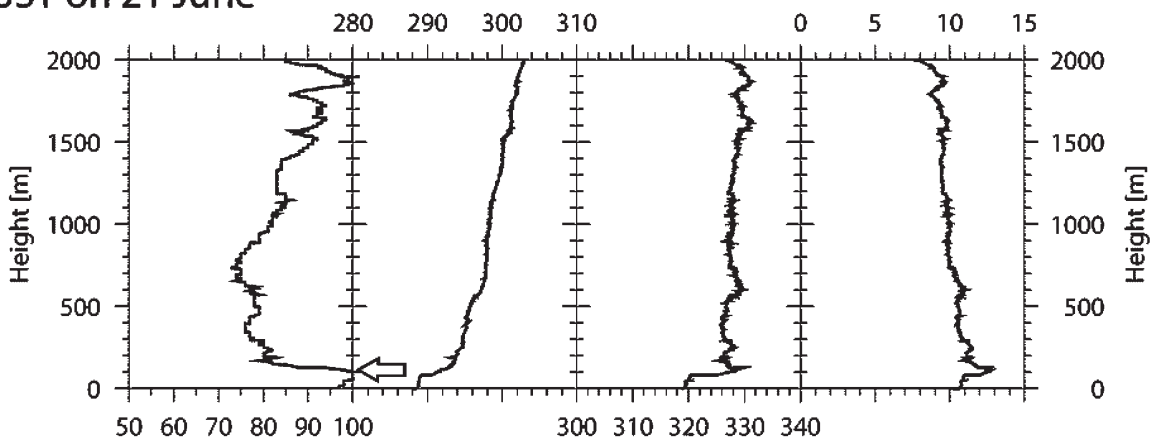

(d) 06:00JST on 21 June

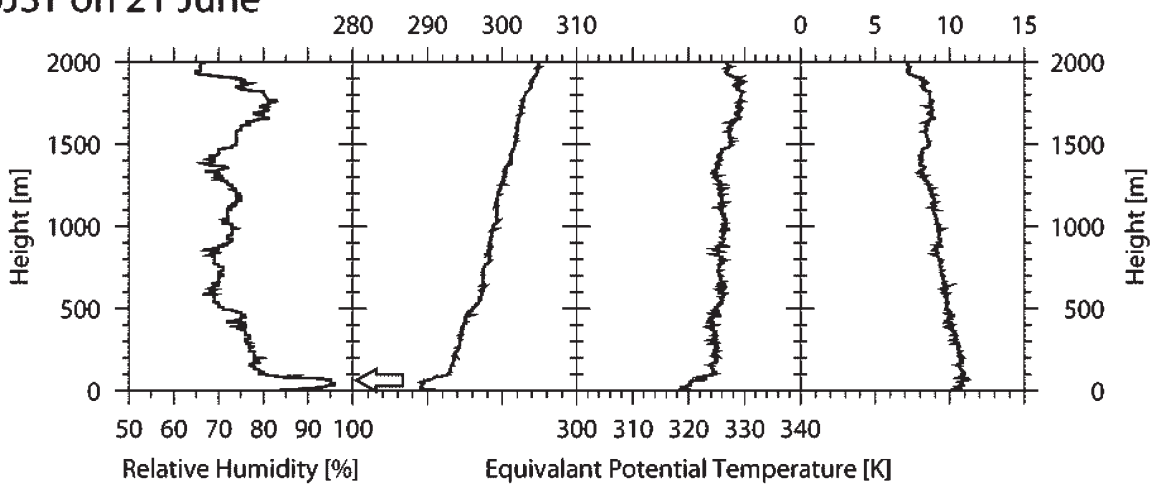

Fig. 2. Vertical profiles of relative humidity (\%), potential temperature (K), equivalent potential temperature (K), and specific humidity $\left(\mathrm{g} \cdot \mathrm{kg}^{-1}\right)$. (a) 21:00 JST on 20 June, (b) 00:00 JST on 21 June, (c) 03:00 JST on 21 June, (d) 06:00 JST on 21 June. Arrows in the figures represent the fog top heights. 


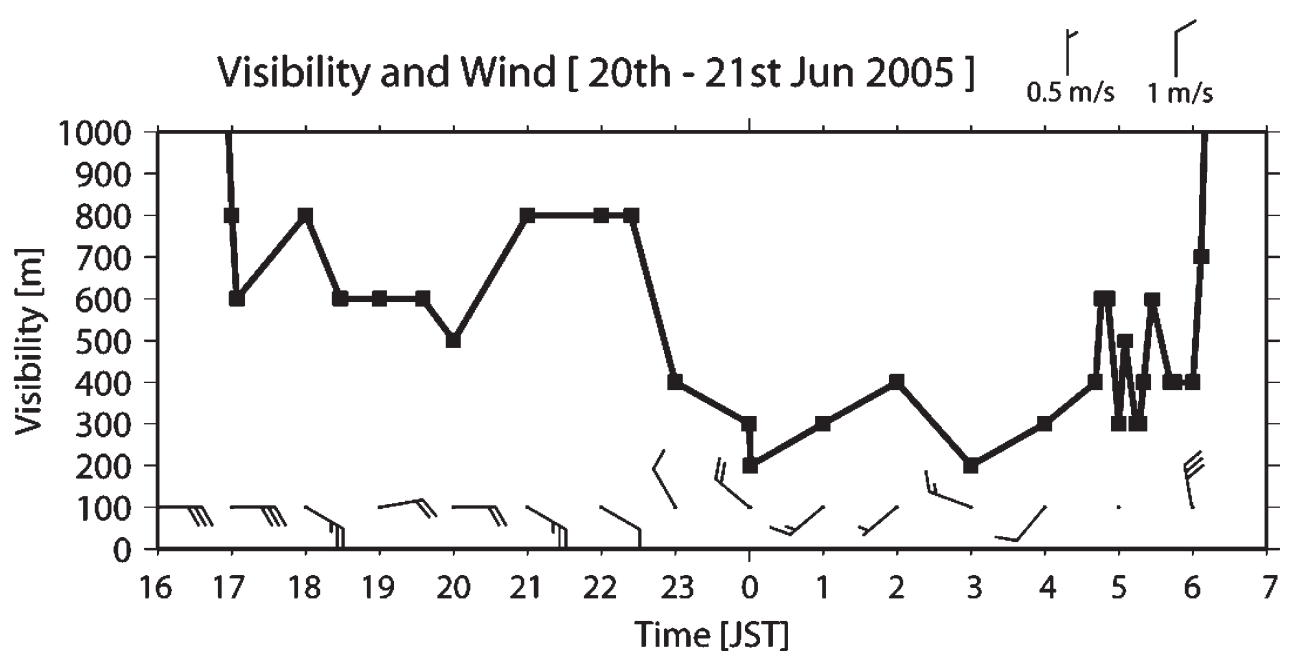

Fig. 3. Visibility (solid line), wind direction and speed (full barb represents $1 \mathrm{~m} \mathrm{~s}^{-1}$ ) on a night between 20 and 21 June.

JST. They decreased at 22:00 JST and increased rapidly from 22:00 JST on 20 June to 00:00 JST on 21 June. They then increased again, from 02:00 to $02: 40$ JST. The concentrations decreased after 04:30 JST, increased around 05:00 JST, and rapidly decreased after that time until the fog dissipated at 06:07 JST. The droplet concentration increased corresponds to visibility minima at 00:00, 03:00 and 05:00 JST. But the visibility minimum at 20:00 JST did not accompany a maximum concentration of small droplets. The rapid decrease of small droplets during the fog dissipation after 05:00 JST suggested evaporation of these droplets.

The number density of droplets smaller than $50 \mu \mathrm{m}$ in diameter ranged from 0.1 to $30 \mathrm{~cm}^{-3}$ as shown in Fig. 4b, an amount almost the same as that found in Hawaiian orographic and maritime cumuli clouds (Squires 1958). Number densities of droplets from 40 to $80 \mu \mathrm{m}$ increased, although those from 10 to $40 \mu \mathrm{m}$ decreased, at 20:00 JST. The decrease is shown in the figure with the concaved line of $10^{-2} \mathrm{~cm}^{-3} \mu \mathrm{m}^{-1}$ around 20:00 JST. The number densities of droplets from 40 to 80 $\mu \mathrm{m}$ decreased until 22:00 JST, and droplets larger than $90 \mu \mathrm{m}$ observed before 22:00 JST disappeared when the wind direction changed and the fog layer became thinner than $100 \mathrm{~m}$. Number densities from 10 to $40 \mu \mathrm{m}$ increased from 20:00 to 21:00 JST, although visibility improved little at the time. Number densities of droplets from 10 to $50 \mu \mathrm{m}$ and droplets from 1 to $5 \mu \mathrm{m}$ increased from 22:00 to 00:00 JST with degrading visibility.
They decreased from 00:00 to 02:00 JST as visibility improved slightly, and increased from 02:00 to 03:00 JST as visibility degraded. Number densities of droplets from 10 to $50 \mu \mathrm{m}$ decreased slowly as visibility improved slowly from 03:00 to 05:30 JST, but the decrease rate was not as rapid as that of droplets between 1 and $5 \mu \mathrm{m}$. The number density of droplets between 10 to $50 \mu \mathrm{m}$ changed rapidly at 05:30 JST and those between 1 and $5 \mu \mathrm{m}$ fluctuated around 05:00 JST with fluctuation of visibility. At 06:07 JST, the visibility improved to $1200 \mathrm{~m}$ as the fog dissipated.

\subsection{Visibility changes with evolutions of fog droplets size spectra}

Extinction coefficient $\sigma\left(\mathrm{m}^{-1}\right)$ calculated from the drop size distribution of fog follows aufm Kampe and Weickmann (1952):

$$
\sigma=2 \pi \Sigma r^{2} N \text {. }
$$

Where $r$ and $N$ are the fog droplet radius (m) and number density $\left(\mathrm{m}^{-3}\right)$, and $\Sigma$ is the summation for all radii. And the coefficient calculated from the visibility follows equation (4) as decided in WMO (World Meteorological Organization).

$$
\sigma=\frac{3}{V},
$$

where $V$ is visibility observed with an optical visibility meter.

We are going to investigate contributions of each size drops to the extinction coefficient in this sec- 
(a) Particle counter $d: 0.3-5 \mu \mathrm{m}$
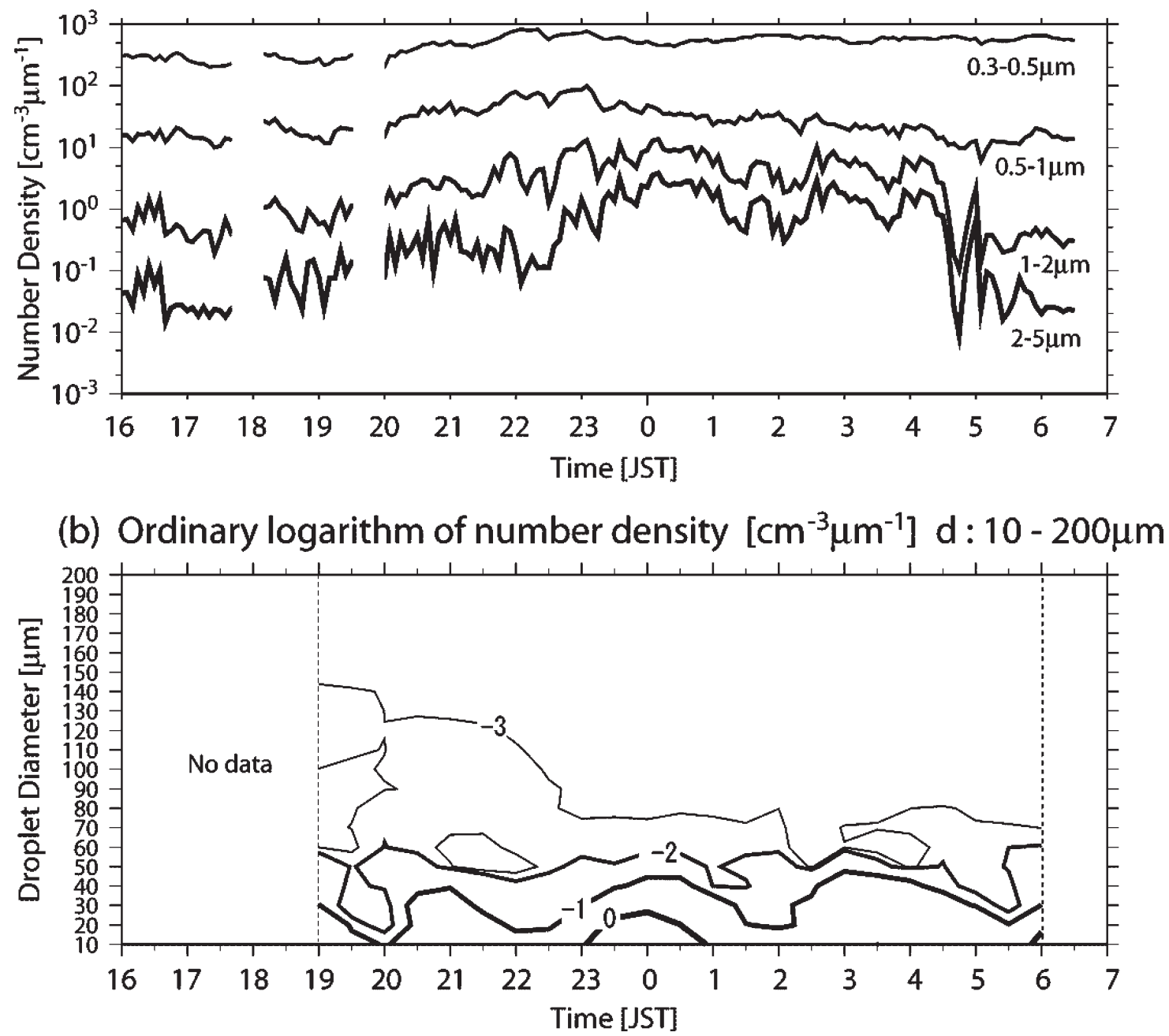

Fig. 4. Evolution of (a) number density for drops between 0.3 and $5 \mu \mathrm{m}$ in diameter and (b) number density $\left(\mathrm{cm}^{-3} \mu \mathrm{m}^{-1}\right)$ for drops between 10 and $100 \mu \mathrm{m}$, on 20 and 21 June. Numerals in (b) represent the ordinary logarithm of the number density.

tion. Before the beginning of the investigation, the extinction coefficients calculated from the drop size distribution of fog following equation (3) and from visibility (4) are plotted in Fig. 5 to show whether the coefficient calculated from the drop size distribution is representative or not in the fog. In the figure, all plots gather around the straight line of unit inclination, and the ratios of the both coefficients are between $1 / 3$ and 3 . So we think the extinction coefficient calculated from the drop size distribution is consistent if we remind that the both instruments have different measuring principle and the observational site and the visibility meter were apart about $1 \mathrm{~km}$ from each other.

Contributions of each drop size to the extinction coefficients are shown in Fig. 6. The contributions of droplets smaller than $5 \mu \mathrm{m}$ in diameter were less than $2 \%$ in this study, and thus their influence on visibility is negligible. A wide range of droplets smaller than $150 \mu \mathrm{m}$ contributed to the extinction coefficient of the first visibility minimum that occurred at 20:00 JST, when onshore winds prevailed and fog layer was thick. At 00:00 and 03:00 JST, droplets smaller than $80 \mu \mathrm{m}$ contributed to the extinction coefficients at the second and the third visibility minima, which were observed when off- 


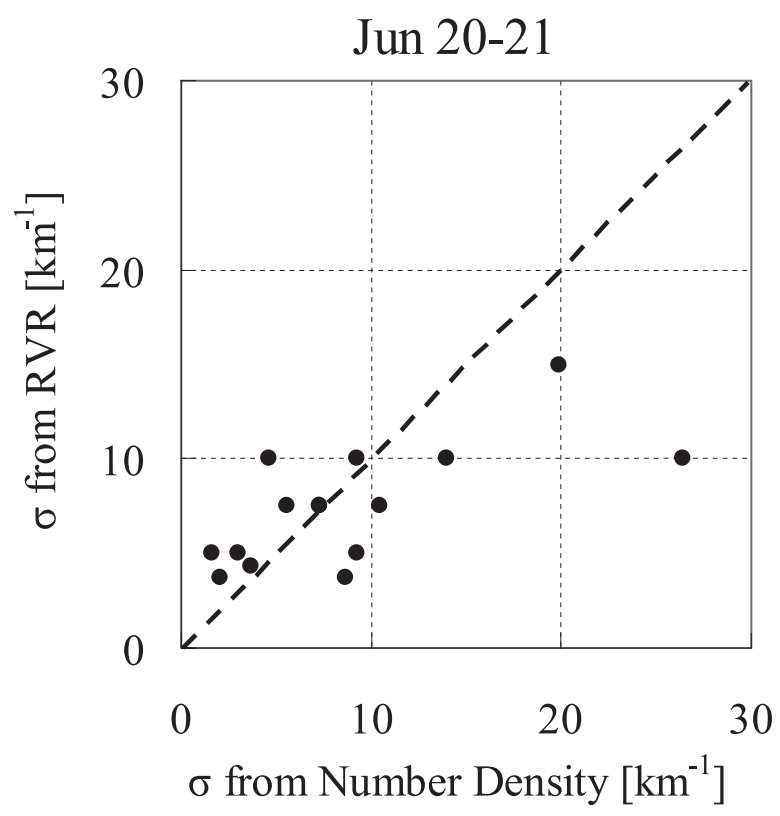

Fig. 5. Comparison of extinction coefficients $(\sigma)$, calculated from drop size distribution and from the visibility.

shore winds prevailed and the fog layer was thin. If we allow a $10 \%$ error in visibility, the extinction coefficients were mainly dominated by droplets between 5 and $100 \mu \mathrm{m}$ when the first visibility minimum was observed at 20:00 JST. After 23:00
JST, the extinction coefficients were dominated by droplets between 5 and $60 \mu \mathrm{m}$. Droplets smaller than $50 \mu \mathrm{m}$ were prevailing when the second and the third visibility minima were observed at 00:00 and 03:00 JST. When the forth visibility minimum was observed at 05:00 JST, droplets smaller than $30 \mu \mathrm{m}$ were prevailing.

\section{Cases on the other days}

\subsection{Upper air soundings}

No RAWIN sonde was launched on 28 June, and thus fog thickness could not be estimated from vertical profiles of relative humidity. But the thickness was assumed to be less than few tens of meters, because the moon and stars were observed through the fog layer.

Vertical profiles of relative humidity, potential temperature, equivalent potential temperature, and specific humidity on 1 and 2 July are shown in Figs. $7 \mathrm{a}, \mathrm{b}, \mathrm{c}$, and $\mathrm{d}$. The fog top height was about $90 \mathrm{~m}$ at 21:00 JST on 1 July, but it rose rapidly to $1490 \mathrm{~m}$ at 0600 JST on 2 July to form a thick humid layer. The profile of specific humidity and potential temperature shows that the fog layer below $90 \mathrm{~m}$ was well mixed at 21:00 JST. But the profiles from 00:00 to 06:00 JST show the fog layer was stable and not mixed. Profiles of equivalent potential temperature shows a stable fog layer consisting of varying neutral layers and stable layers. For example, layers around $400 \mathrm{~m}, 200 \mathrm{~m}$, and $100 \mathrm{~m}$ were neutral at

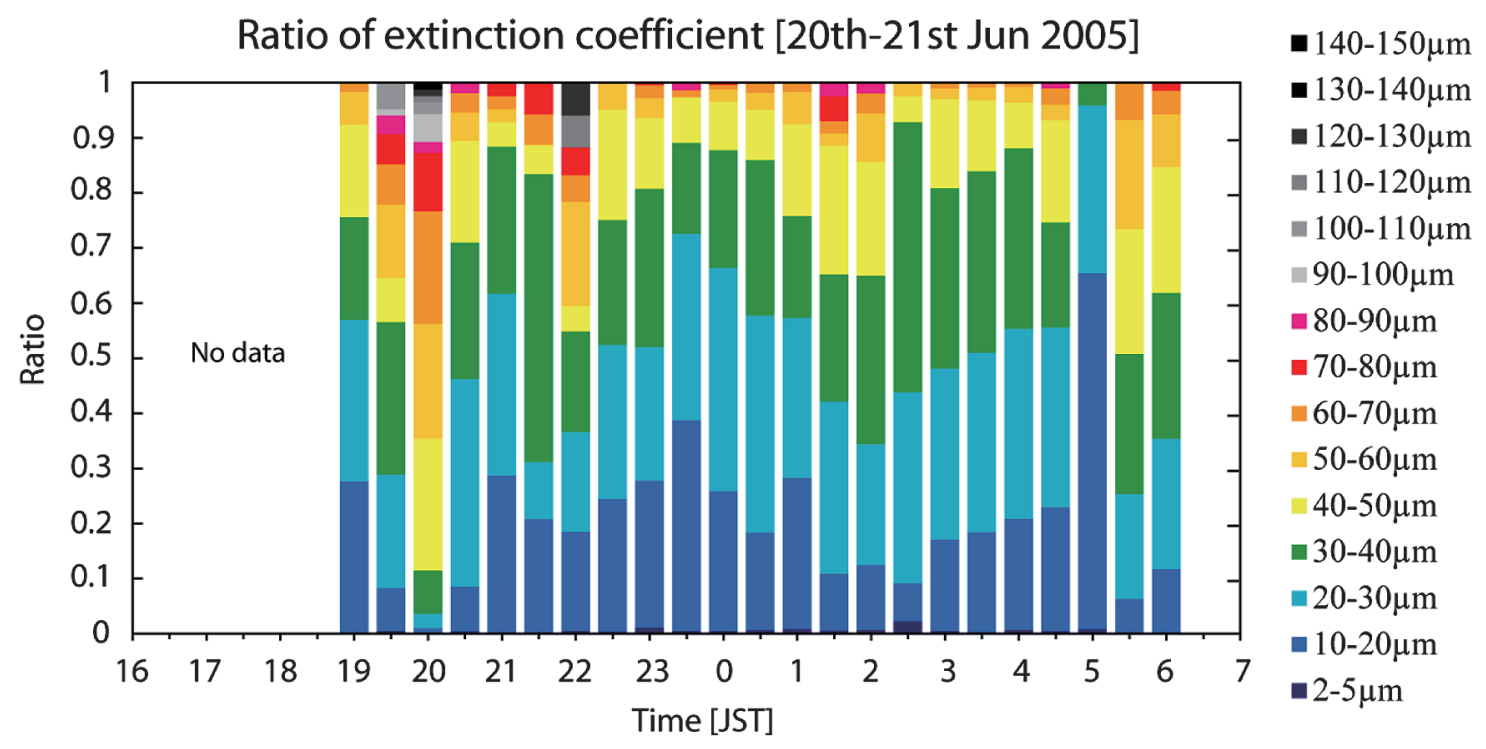

Fig. 6. Contribution ratios of each drop size to the extinction coefficients on 20 and 21 June. 
(a) 21:00JST on 1 July Potential Temperature [K]

Specific Humidity [ $\mathrm{g} \mathrm{kg}^{-1}$ ]

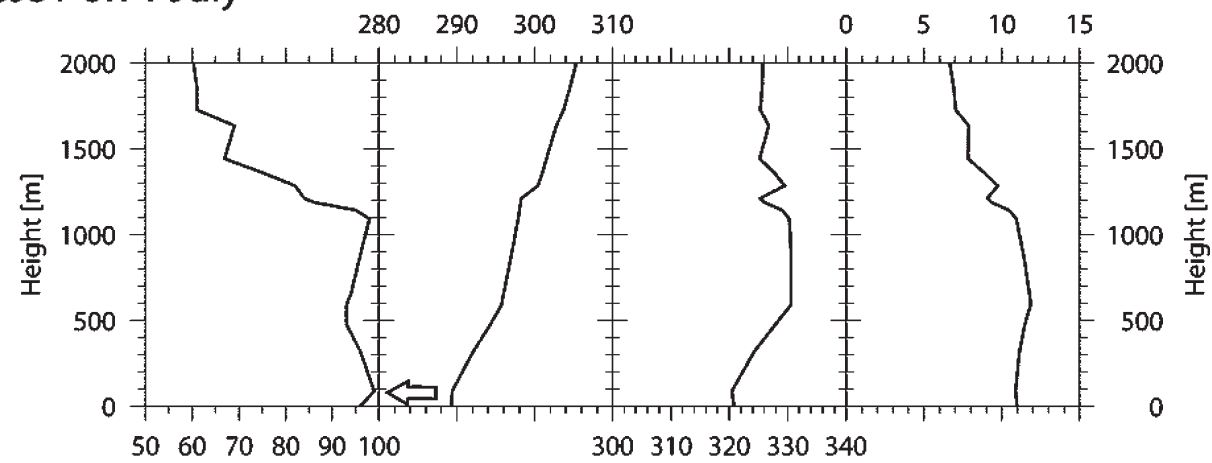

(b) 00:00JST on 2 July

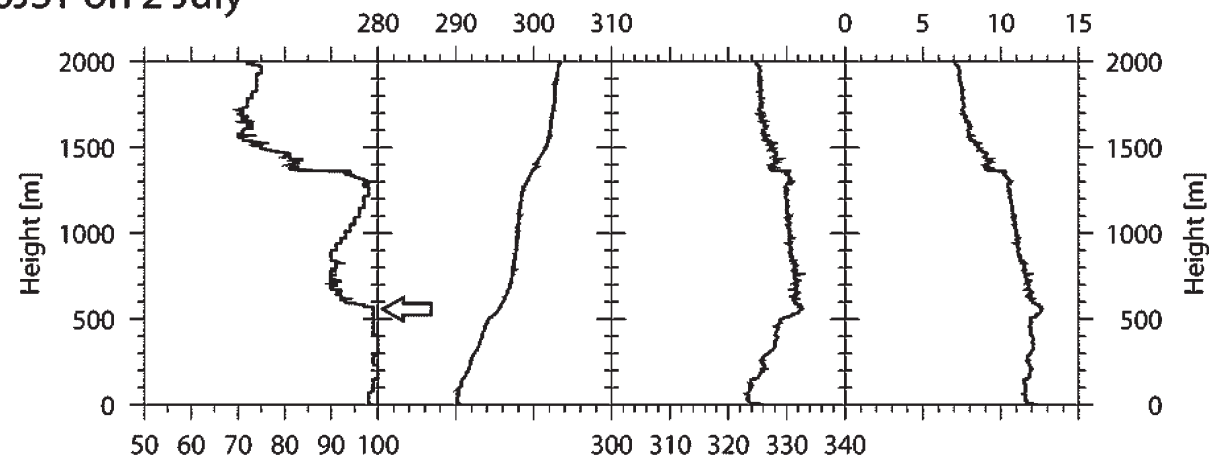

(c) 03:00JST on 2 July

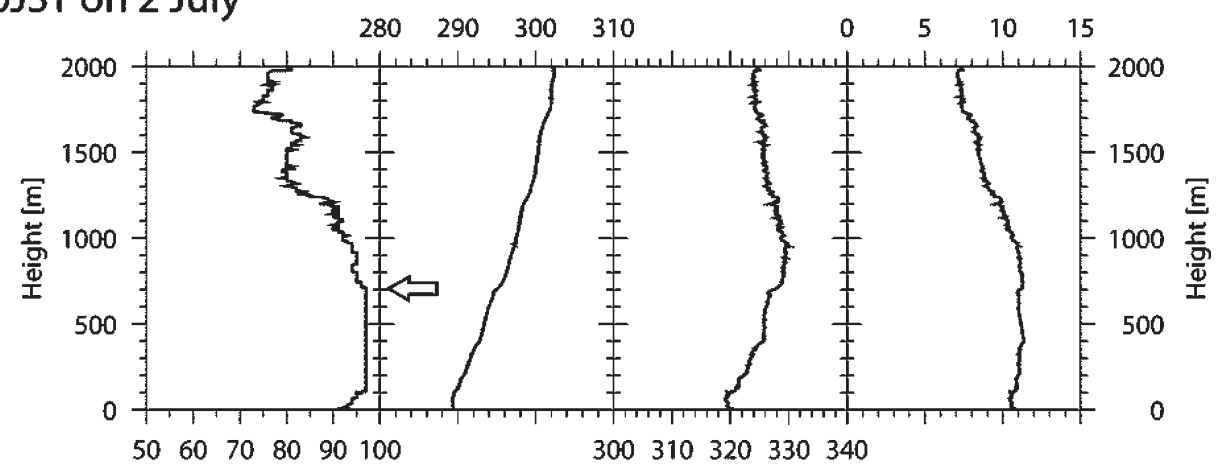

(d) 06:00JST on 2 July

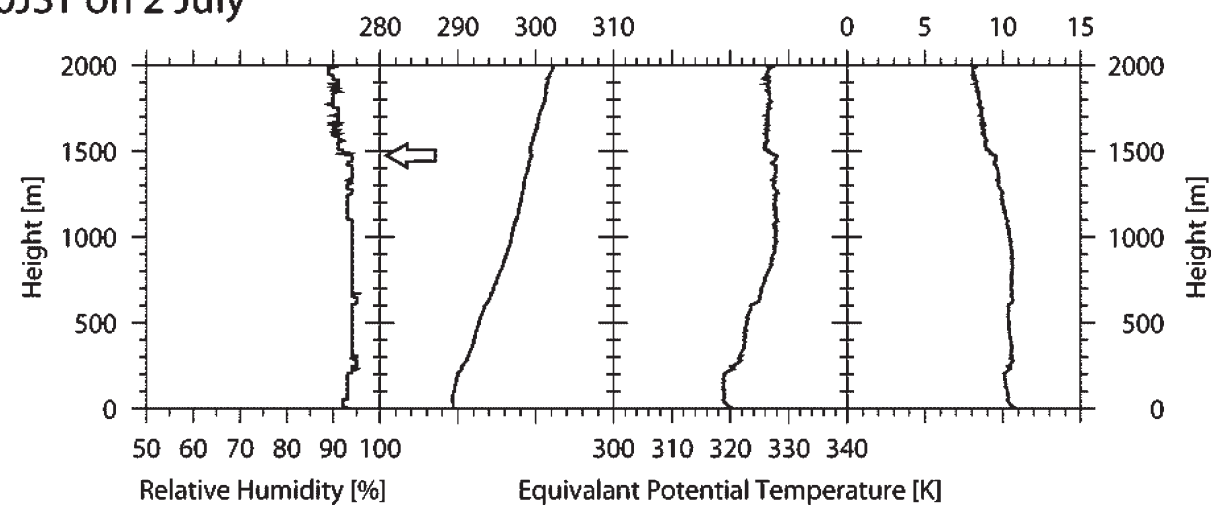

Fig. 7. Same as Fig. 2, but for at (a) 21:00 JST on 1 July, (b) 00:00 JST, (c) 03:00 JST, (d) 06:00 JST on 2 July. 
00:00 JST; layers around $600 \mathrm{~m}$ and $50 \mathrm{~m}$ were neutral at 03:00 JST; and layers around $1200 \mathrm{~m}, 500 \mathrm{~m}$, and $100 \mathrm{~m}$ were neutral at 06:00 JST.

Vertical profiles of relative humidity, potential temperature, equivalent potential temperature, and specific humidity on 7 and 8 July are shown in Figs. $8 \mathrm{a}$ and $\mathrm{b}$. The fog top height was about $1030 \mathrm{~m}$ at 21:00 JST on 7 July and was $780 \mathrm{~m}$ at 09:00 JST on 8 July. Profiles of equivalent potential temperature show that the fog layers below $750 \mathrm{~m}$ at 21:00 JST and below $450 \mathrm{~m}$ at 09:00 JST were well mixed, but humid fog layers above these heights were not mixed. Such a neutral humid layer under a stable humid layer suggests that the layer was formed by convection and suppressed by a thermally stable layer. These types of thick fog layers influenced by convection generally occur under stratocumuli. These thick fog layers described above may be separated to a fog layer and some cloud layers, because the thick fog layers were not well mixed as suggested with the equivalent potential temperature profiles. But these figures clearly suggest that thick humid layers grew up in these days.

(a) 21:00 JST on 7 July

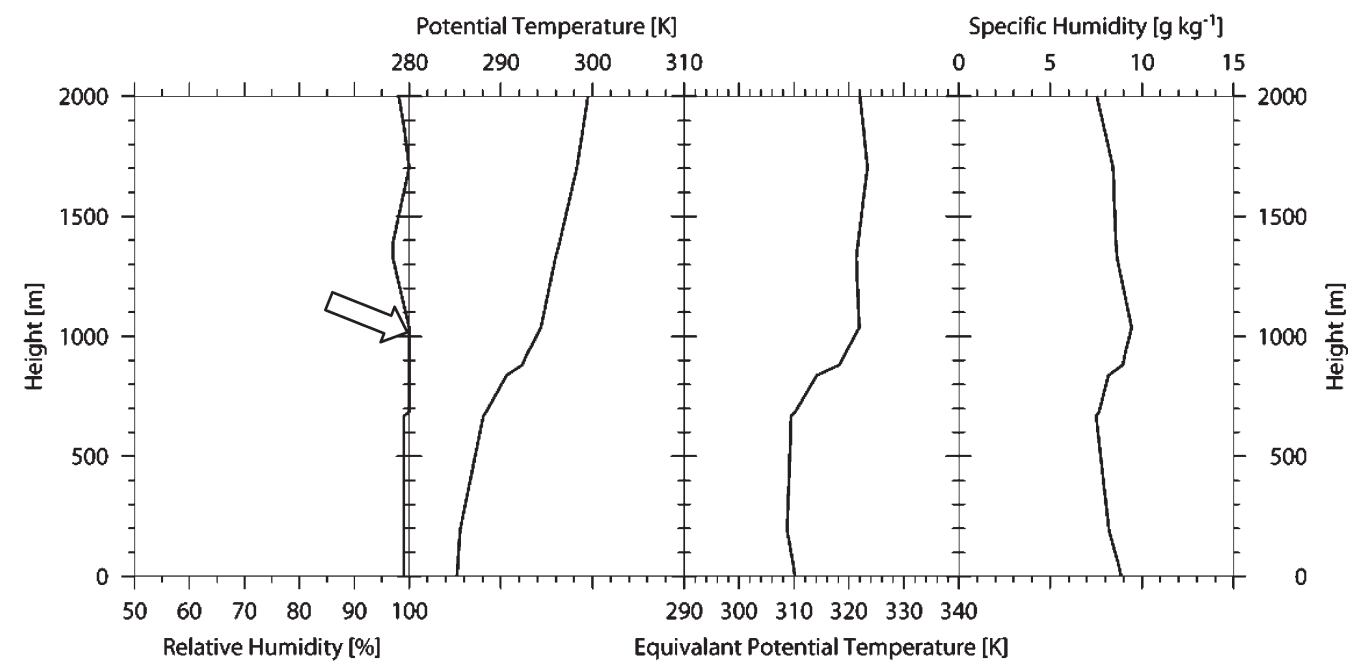

(b) 09:00 JST on 8 July

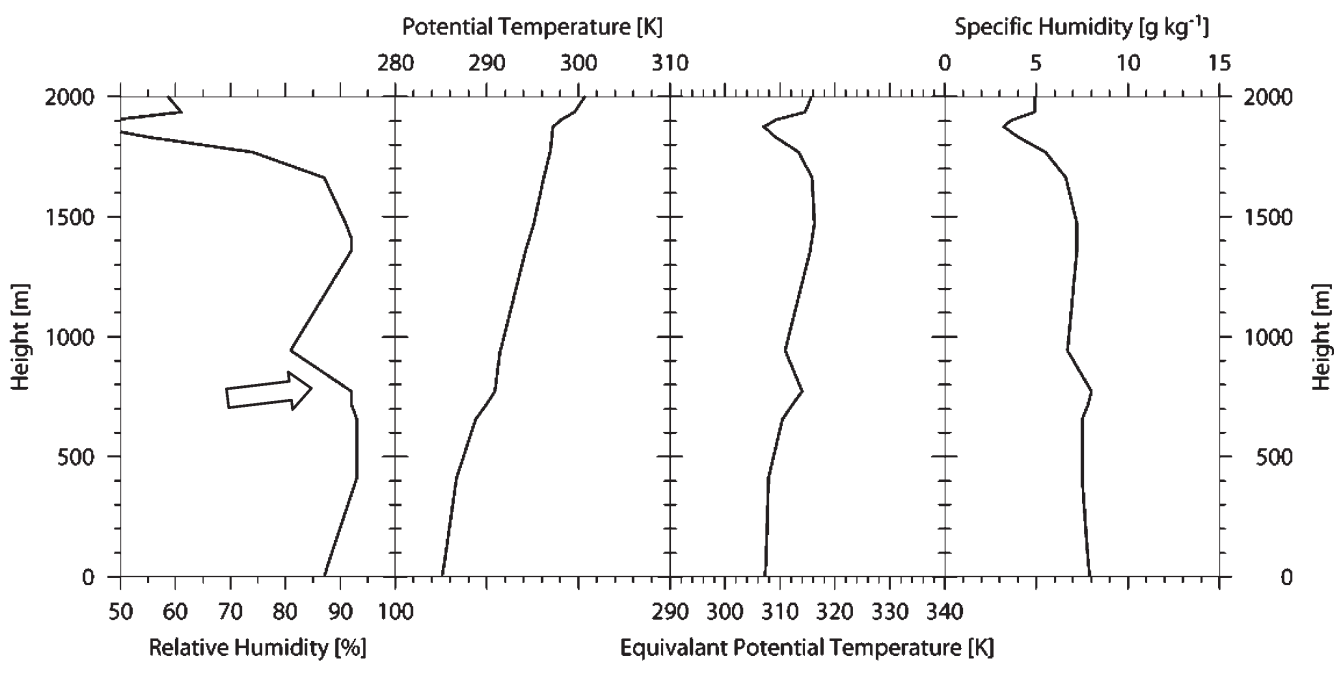

Fig. 8. Same as Fig. 2, but for at (a) 21:00 JST on 7 July, and (b) 09:00 JST on 8 July. 


\subsection{Visibility and other meteorological elements} 4.2.1 Fog on 27-28 June

Fog was observed at Misawa Air Base after a low pressure system passed and weak rain ceased at 19:55 JST on 27 June. Visibility and wind at the air base from 22:00 JST on 27 June to 06:00 JST on 28 June are shown in Fig. 9. Visibility minima occur around 22:18 and 00:00 JST, and visibility decreases rapidly from 02:00 to 03:00 JST with change of wind direction from NNW to E. It shows another minimum at 05:15 JST, with onshore wind conditions. Evolution of droplet number density is shown in Fig. 10a. The number density was not observed at 22:18 JST. Many drops smaller than $30 \mu \mathrm{m}$ in diameter were observed at the third visibility minimum of 03:00 JST, and the concentration of small drops decreased rapidly after that time. The concentration of drops smaller than $20 \mu \mathrm{m}$ increased at 05:30 JST, when the fourth visibility minimum was observed. Contributions of each drop size to the extinction coefficients are shown in Fig. 10b. Following the increasing concentration of small drops at the third and the forth visibility minima, the contribution of drops smaller than 40 $\mu \mathrm{m}$ and $50 \mu \mathrm{m}$ increased at 03:00 and 05:30 JST, respectively.

\subsubsection{Fog on 1-2 July}

Shower rain was observed from 12:00 to 18:00 JST on 1 July at Misawa Air Base. Fog was observed after the rain ceased. Visibility at the air base from 20:00 JST on 1 July to 08:00 JST on 2 July is shown in Fig. 11. Visibility minima occurred at 20:39 and 22:55 JST on 1 July, and at 04:55 and 06:37 JST on 2 July. A constant low value of about $400 \mathrm{~m}$ persisted from 23:55 to 01:55 JST. Droplet size spectra from 21:00 to 05:00 JST are shown in Fig. 12a. Small drops of smaller than 50 $\mu \mathrm{m}$ prevailed before 22:00 JST when the fog layer was thin (see Fig. 7a), then small drops increased rapidly, and drops larger than $100 \mu \mathrm{m}$ began to be observed at the second visibility minimum of 23:00 JST under the thick fog layer (see Fig. 7b). The concentration of drops smaller than $50 \mu \mathrm{m}$ decreased gradually from 23:00 JST, and the concentration of drops larger than $80 \mu \mathrm{m}$ increased from 02:00 to 05:00 JST under a thick fog layer (see Figs. 7b, c, and d).

Contributions of each drop size to the extinction coefficients from 21:00 to 05:00 JST are shown in Fig. 12b. Drops smaller than $80 \mu \mathrm{m}$ caused degradation of visibility, especially drops smaller than
$50 \mu \mathrm{m}$ were prevailing, before 22:00 JST. When the second visibility minimum was observed at $23: 33$ JST, large drops increased and drops between 10 and $130 \mu \mathrm{m}$ caused the visibility minimum. The influences of large drops on the degradation of visibility increased after 23:00 JST, and drops between 10 to $200 \mu \mathrm{m}$ caused the third visibility minimum at 05:00 JST.

\subsubsection{Fog on 7-8 July}

On the morning of 7 July, Misawa Air Base was covered by stratocumulus with a low ceiling, and drizzle was observed. A pilot reported the cloud top height to be about $1000 \mathrm{~m}$ at 15:00 JST. Visibility, wind direction and wind velocity at the air base from 14:00 JST on 7 July to 08:00 JST on 8 July are shown in Fig. 13. The visibility was near $3000 \mathrm{~m}$ on the 7 , and the visibility minimum occurred at 04:55 JST on the 8 .

Evolutions of drop size distributions and the contributions of each drop size to the extinction coefficients from 15:00 to 05:00 JST are shown in Figs. 14a and b. Large drops between 50 and $200 \mu \mathrm{m}$ were observed through this period, while the visibility remained around $3000 \mathrm{~m}$. Figure 14a shows slight increase of drops between 10 and $50 \mu \mathrm{m}$ and drops between 100 and $150 \mu \mathrm{m}$ from 04:30 to 05:00 JST at the visibility minimum. And drops between 50 and $100 \mu \mathrm{m}$ increased at that time, also. Analysis of the contributions of each droplet size to the extinction coefficient showed that droplets larger than $80 \mu \mathrm{m}$ were the primary influence upon the visibility of about $3000 \mathrm{~m}$ from 15:00 to 23:00 JST on 7 July. The contributions of droplets smaller than $80 \mu \mathrm{m}$ increased in the rapid degradation of visibility at 05:00 JST on 8 July.

\section{Discussions and summary}

We summarize the observational results in Table 1. It shows the observational date and time, visibility, wind direction, fog thickness, diameter of the largest drop in the fog, existence of drizzle (drops larger than $200 \mu \mathrm{m}$ in diameter), drop diameter at $90 \%$ of extinction coefficient in the fog, and representative drop size. The representative drop size (Drep) is calculated as weighted mean of drop size by contributions of each drop size to the extinction coefficients.

$$
\text { Drep }=\frac{\sum_{i} \sigma_{i} r}{\sum_{i} \sigma_{i}},
$$




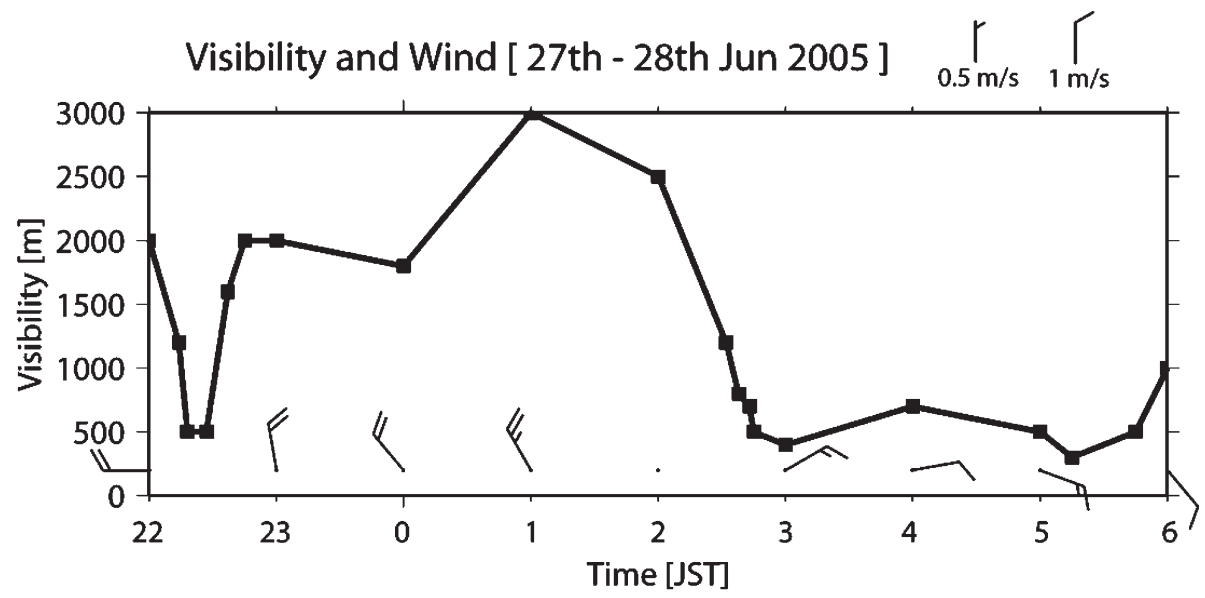

Fig. 9. Same as Fig. 3, but for the night between 27 and 28 June.

(a) Ordinary logarithm of number density $\left[\mathrm{cm}^{-3} \mu \mathrm{m}^{-1}\right]$

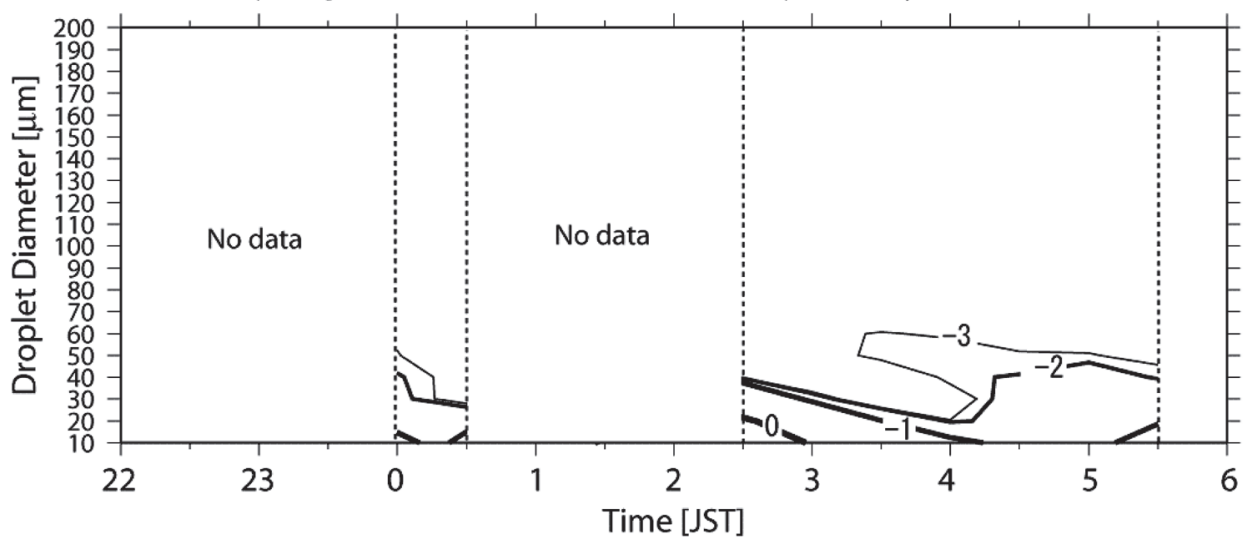

(b) Ratio of extinction coefficient

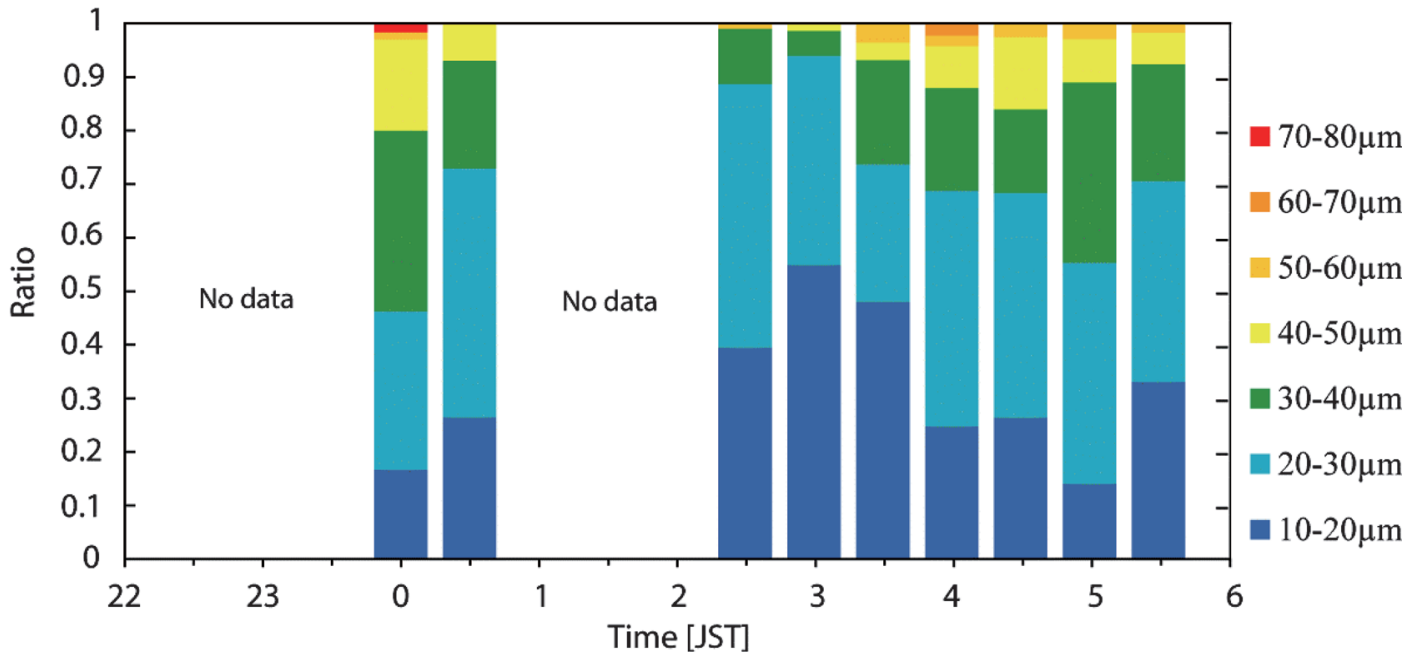

Fig. 10. Evolutions of (a) number density of droplets, and (b) contribution ratios of each drop size to the extinction coefficient from 00:00 to 06:00 JST on 28 June. 


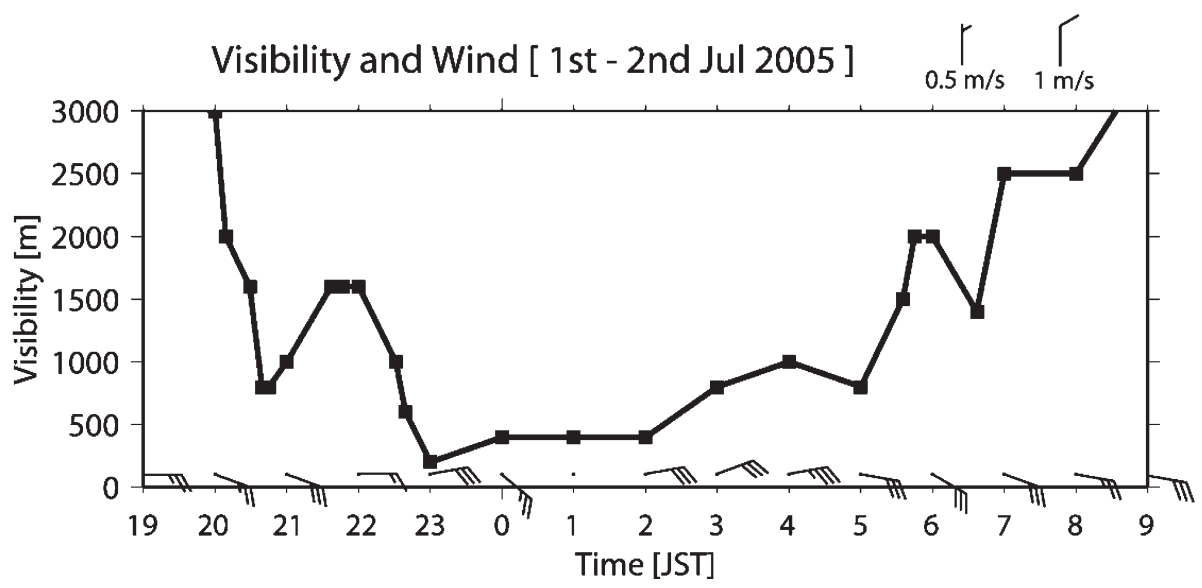

Fig. 11. Same as Fig. 3, but for the night of 1 July.

(a) Ordinary logarithm of number density $\left[\mathrm{cm}^{-3} \mu \mathrm{m}^{-1}\right]$

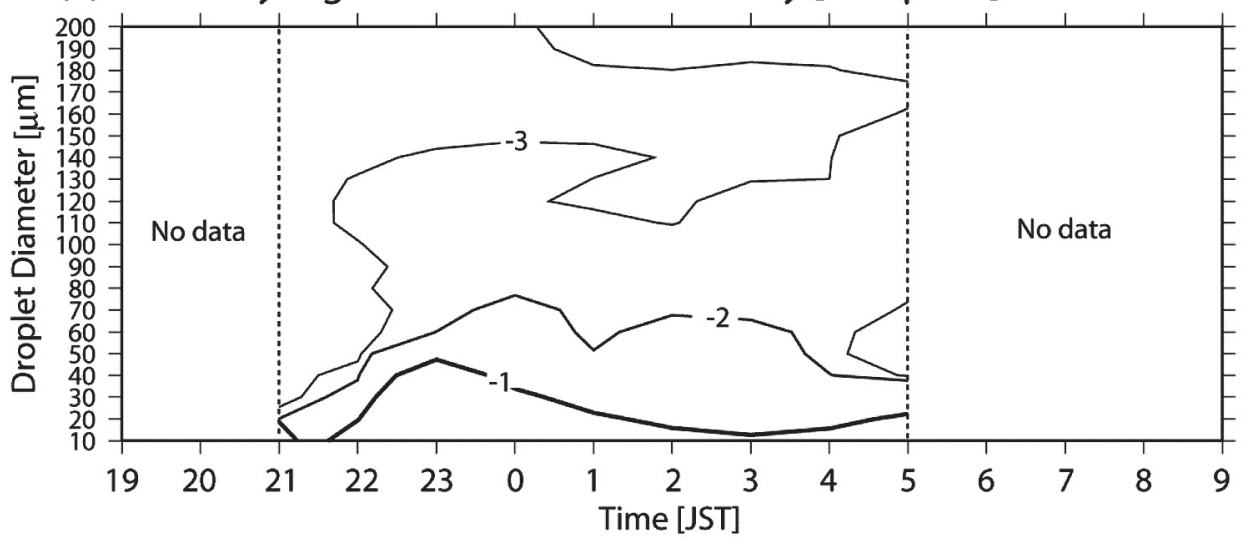

(b) Ratio of extinction coefficient

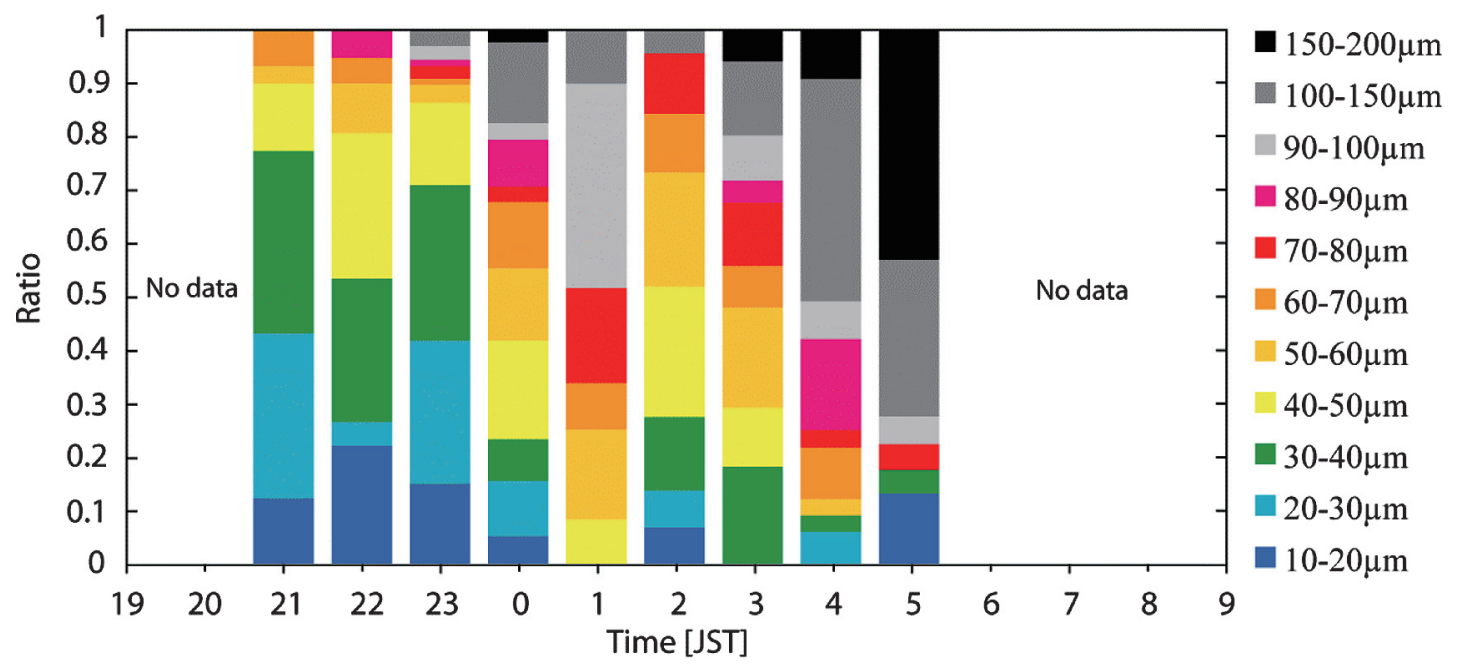

Fig. 12. Same as Fig. 9, but from 21:00 JST on 1 to 05:00 JST on 2 July. 


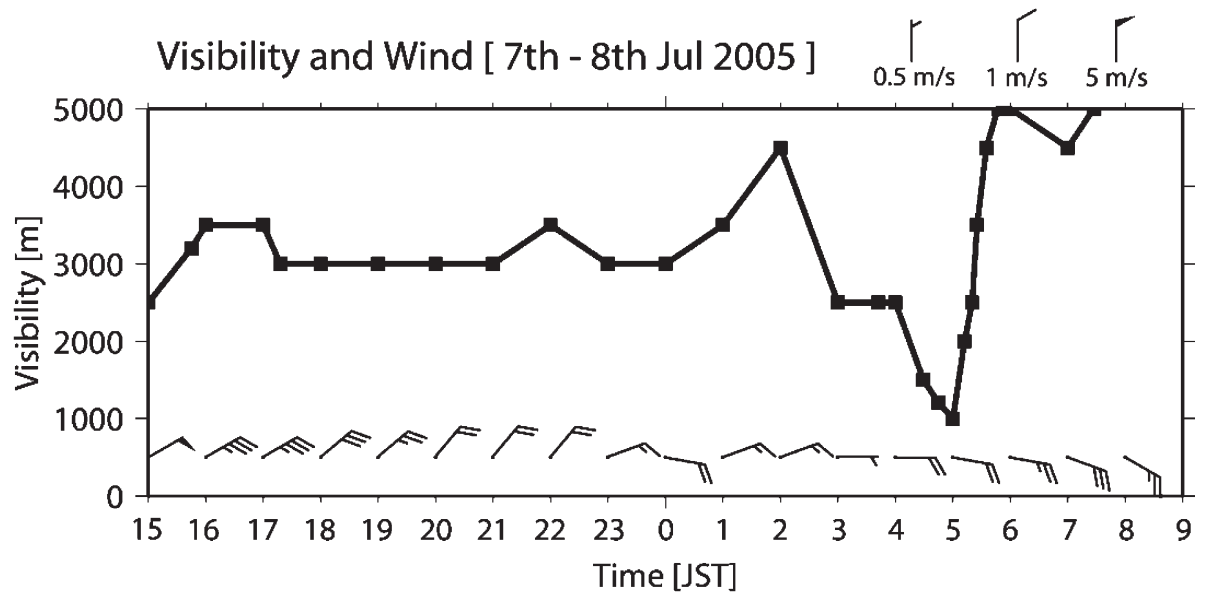

Fig. 13. Same as Fig. 3, but for the night of the 7 July.

(a) Ordinary logarithm of number density $\left[\mathrm{cm}^{-3} \mu \mathrm{m}^{-1}\right]$

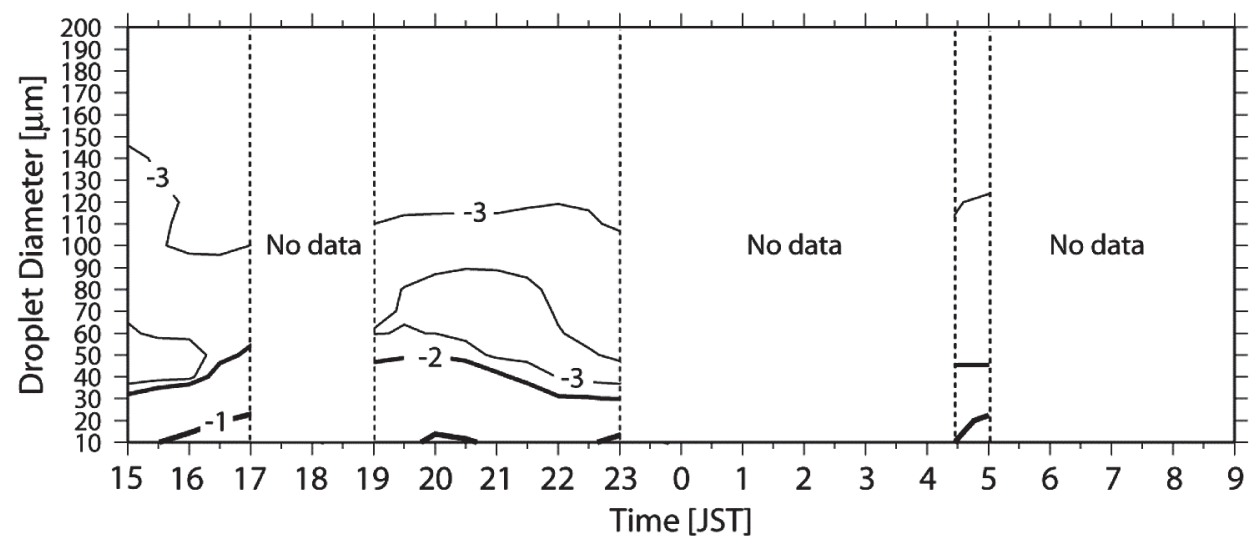

\section{(b) Ratio of extinction coefficient}

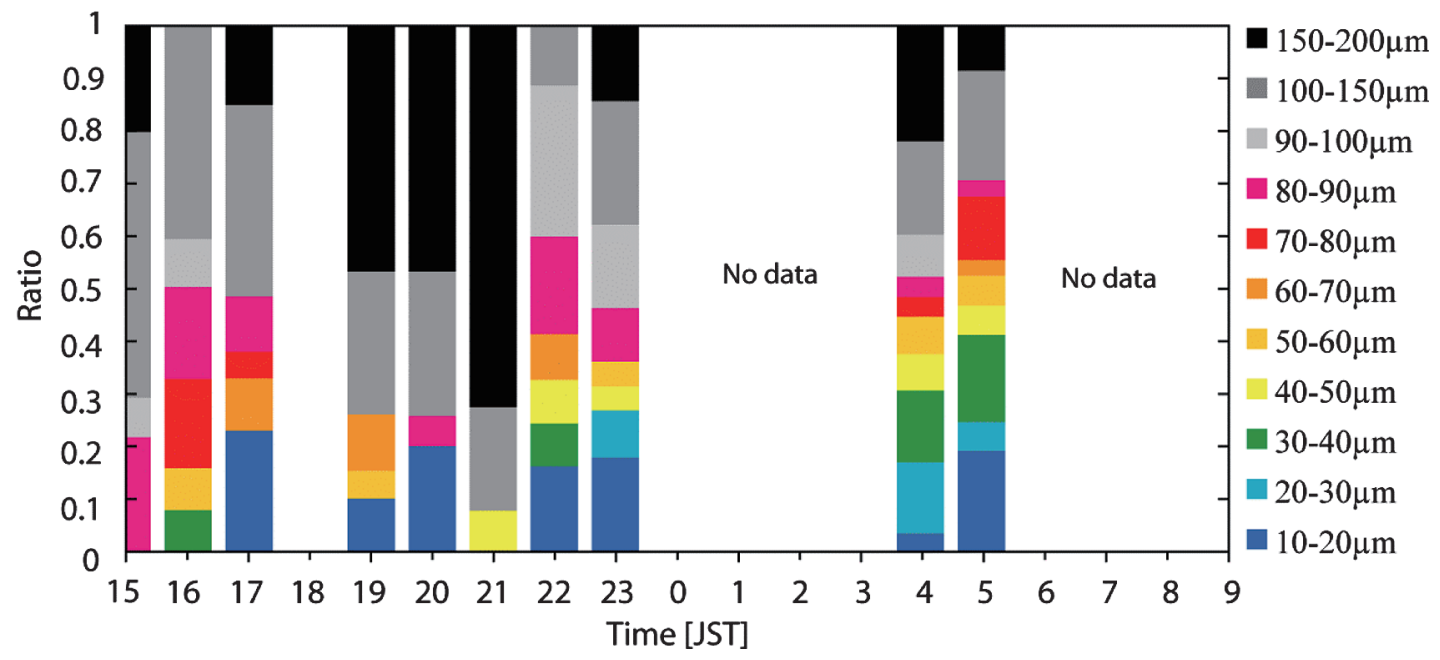

Fig. 14. Same as Fig. 10, but from 15:00 to 05:00 JST on 7-8 July. 
Table 1. Summary of observational results. They represent date, time, visibility, wind direction, fog thickness, diameter of the largest fog drop, existence of drizzle drops (larger than $200 \mu \mathrm{m}$ in diameter), fog drop diameter at $90 \%$ of extinction coefficient, and representative drop size (Drep).

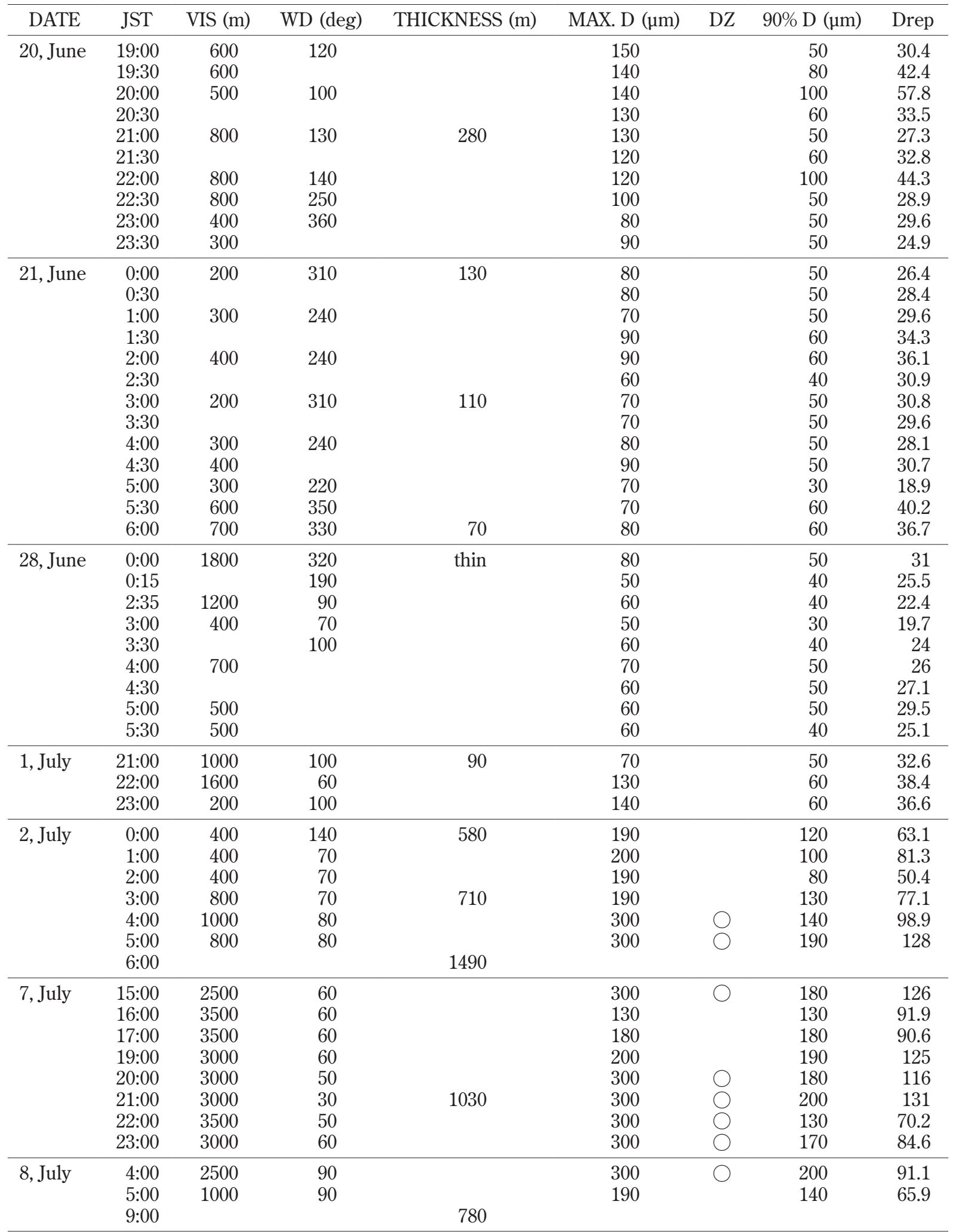


where $\sigma_{i}$ is the contribution of each drop size to the extinction coefficient.

These results suggest that fog thickness (or thickness of humid layers) and the size of the largest fog droplets were related. Scatter plots of fog thickness (or thickness of humid layers) and the largest droplet size, are shown in Fig. 15, to validate this relationship. Fog top height is assumed by interpolation with time when wind direction was little changed. On 20 June, it is assumed to be 280 $\mathrm{m}$ before the wind direction changed at 22:30 JST and is assumed to be $30 \mathrm{~m}$ without RAWIN sonde data on the night of 27 June. Figure 15a shows that the size of the largest fog drops increased with fog thickness. Coalescence is known to be an important mechanism for creating droplets larger than 40 $\mu \mathrm{m}$ in diameter and Fig. 15a shows that the coalescence occurred more effectively in thick fog layers than thin one. The relation between fog drop size

(a)

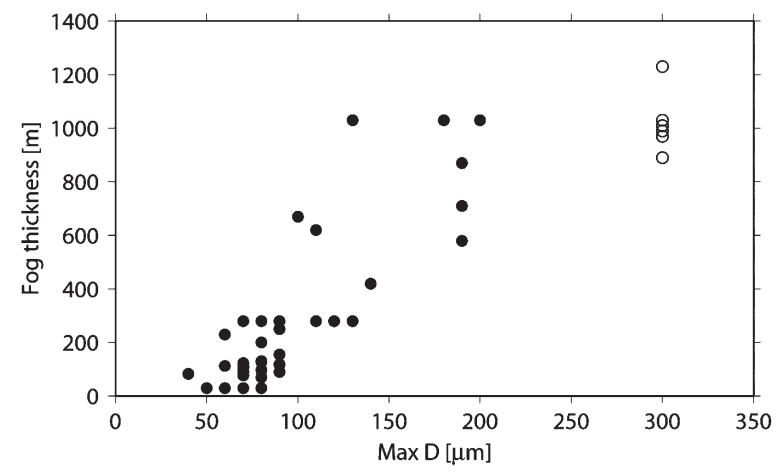

(b)

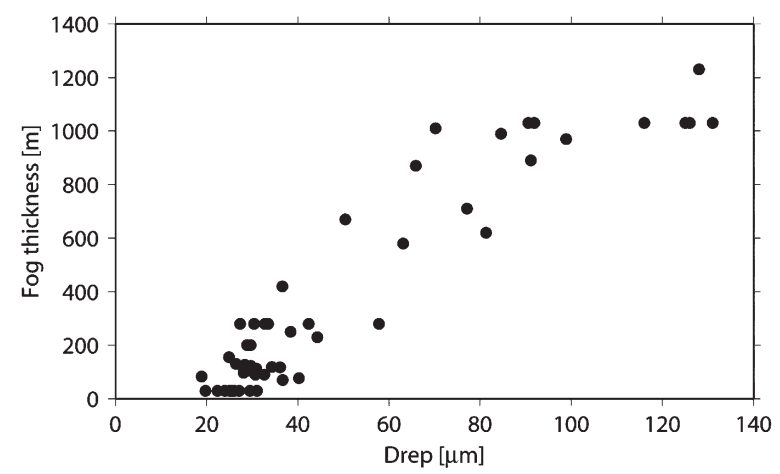

Fig. 15. Scatter plots of fog thickness and (a) the largest drop size in the fog and (b) the representative fog drop size (Drep). Drizzle drops (Drops larger than $200 \mu \mathrm{m}$ in diameter) are represented by open circle at $300 \mu \mathrm{m}$. and fog thickness is better for the representative drop sizes (Drep) (Fig. 15b). The representative drop size is introduced here to avoid influences of large drops contributing little to the extinction coefficient and to show the representative drop sizes which cause the extinction coefficients. Therefore, influences of large drops on the extinction coefficient increased with increasing fog layer thickness (or thickness of humid layers).

Relations between the largest drop size and fog thickness are described in Homma et al. (1962), also. They showed drizzle drops in fog layers thicker than $400 \mathrm{~m}$, and fog drops of $200 \mu \mathrm{m}$ in diameter even in shallow fog of $200 \mathrm{~m}$ thickness. They also described that the sea fog always contained larger drops than $70 \mu \mathrm{m}$ in diameter. In our study, drizzle drops are observed in thicker fog than $800 \mathrm{~m}$, fog drops larger than $200 \mu \mathrm{m}$ are not observed in fog of $200 \mathrm{~m}$ thickness, and the under limit of the largest drop size is $40 \mu \mathrm{m}$. These results are similar to each other with some little differences. And causes of these differences are not clear.

Evolutions of contributions of each drop size to the extinction coefficients around the visibility minima are investigated hereafter. The visibility degraded rapidly four times in this study. They are visibility minima at 00:00 JST on 21 June, 03:00 JST on 28 June, 23:00 JST on 1 July, and 05:00 JST on 8 July. At the visibility minimum of 00:00 JST on 21 June, the contributions of droplets smaller than $50 \mu \mathrm{m}$ to the extinction coefficients increased under the $130 \mathrm{~m}$ thick fog layer as shown in Fig. 6. At $03: 00$ on 28 June the visibility minimum was observed under the thin fog layer. Contributions of each drop size to the extinction coefficients in Fig. 10b show that the contributions of drops smaller than $40 \mu \mathrm{m}$ increased at the time. At the visibility minimum of 23:00 JST on 1 July small drops increased rapidly, and drops larger than 100 $\mu \mathrm{m}$ began to be observed (see Fig. 12a) when fog thickness was growing from 90 to $580 \mathrm{~m}$. At the visibility minimum of 05:00 JST on 8 July, drops between 10 and $150 \mu \mathrm{m}$ slightly increased from 04:00 to 05:00 JST under a thick humid layer as shown in Fig. 14a. Analysis of the contributions of each droplet size to the extinction coefficient showed the contributions of droplets smaller than $80 \mu \mathrm{m}$ increased at the visibility minimum (see Fig. 14b). Summarizing above results, small drops seem to increase when visibility degrades rapidly. So scatter plots of the representative drop diameter (Drep) and visibility are shown in Fig. 16 to clarify rela- 
tions between drop size distribution and visibility when visibility degrades rapidly. At first glance, no relations between drop size and visibility can be seen in the figure. But Drep always decreases at the four visibility minima. So it is understood that increasing small drops are important for rapid visibility degrading. Yanagisawa et al. (1986) said that smaller drops than $50 \mu \mathrm{m}$ in diameter were prevailing in fogs with lower radar echo height than $400 \mathrm{~m}$, and visibility was short in strong radar reflectivity in fogs formed of small drops. Above results are similar to this description but we find increase of small drops is important for rapid visibility degrading not in thin fogs but also in thick fogs.

There are two cases where increasing large drops caused visibility minima. They are at 20:00 JST on 20 June and 05:00 JST on 2 July. Number densities of drops from 40 to $80 \mu \mathrm{m}$ increased and those from 10 to $40 \mu \mathrm{m}$ decreased at the visibility minimum at 20:00 JST on 20 June under the $280 \mathrm{~m}$ thick fog layer as shown in Fig. 4. So, contributions of large drops to the extinction coefficient were increased as shown in Fig. 6. From 02:00 to 05:00

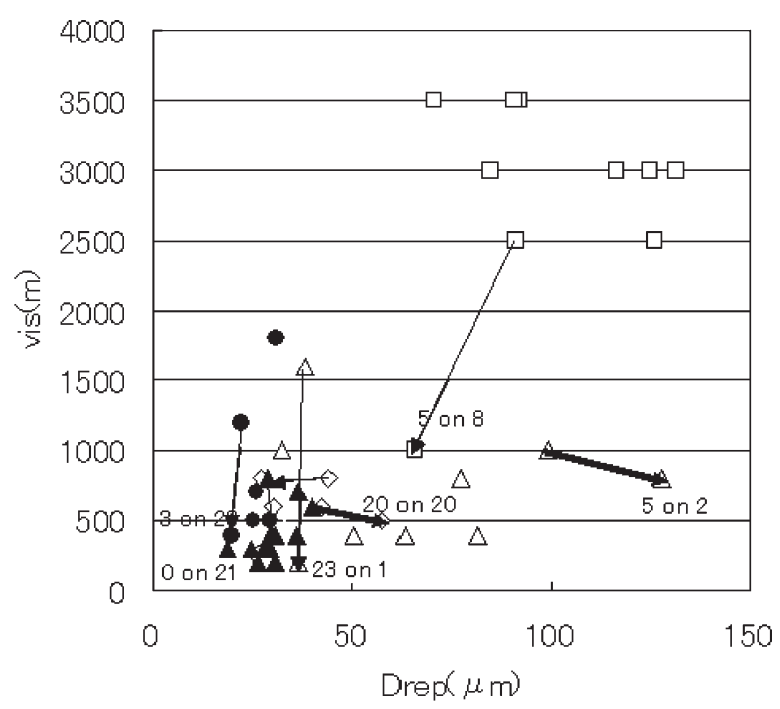

Fig. 16. Scatter plots of the representative diameters of drops (Drep) and visibility (vis). $\bigcirc, \square$ represent 28 June, $1-2$ July and 7-8 July. $\nabla$, and $\boldsymbol{\Delta}$ represent data before and after 22:00 JST 20 June. Numerical values in the figure represent time and date when the visibility minima were observed and arrows in the figure represent time sequence before the minima.
JST on 2 July the concentration of drops larger than $80 \mu \mathrm{m}$ increased under a thick fog layer as shown in Fig. 12a. And Fig. 12b shows that contributions of larger drops than $90 \mu \mathrm{m}$ to the extinction coefficient increased at the visibility minimum of 05:00 JST. These visibility drops were not rapid and appeared under thicker fog layers than $280 \mathrm{~m}$.

Fogs are sometimes classified by wind direction into fog from land and fog from sea. In this study, fog in offshore wind was observed only after 20:30 JST on 20 June and the representative drop sizes were smaller than $40.2 \mu \mathrm{m}$ in the period. Though the representative drop sizes of fog on 28 June were smaller than $31 \mu \mathrm{m}$ in onshore wind and smaller than those described above. So fogs can not be classified by only wind direction. Fogs must be understood more dynamically and fog thickness may be one of good parameters to represent dynamics in a fog.

In order to clarify which drops cause short visibility, scatter plots of the drop diameter at $90 \%$ of extinction coefficient and fog thickness are shown in Fig. 17. In the figure, drops smaller than $60 \mu \mathrm{m}$ caused short visibility under thinner fog layer than $130 \mathrm{~m}$. In thicker fog layers, drop size distributions spread and the drop diameters at $90 \%$ of extinction coefficient increase with increasing fog thickness. Coalescence is known to be an important mechanism for creating droplets larger than $40 \mu \mathrm{m}$ in diameter, and is known to be more effective in thick cloud layers with high liquid water content. So the representative drop sizes smaller than $40 \mu \mathrm{m}$ for thinner fog layer than $130 \mathrm{~m}$ are expected to be strongly influenced by condensation processes and the above result drops smaller than $60 \mu \mathrm{m}$ caused

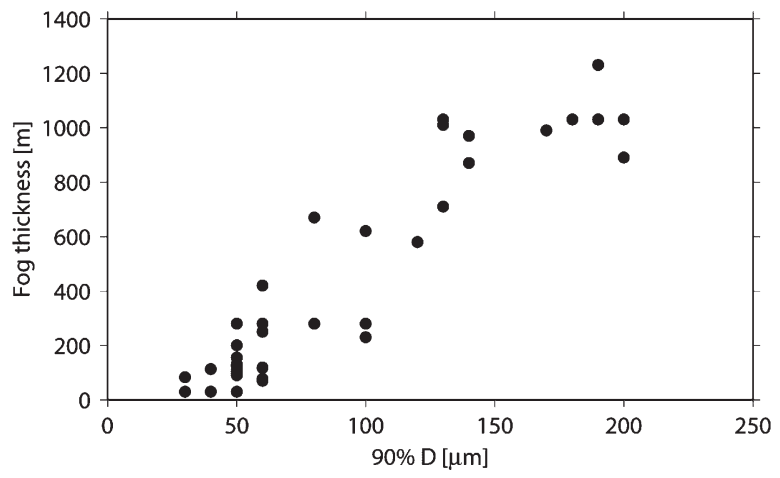

Fig. 17. Scatter plots of the drop diameter $(\mu \mathrm{m})$ at $90 \%$ of extinction coefficient and fog thickness (m). 
short visibility under the thin fogs means that almost fog drops which support the short visibility under the thin fog layers are formed through condensation processes.

\section{References}

aufm Kampe, H.J. and H.K. Weickmann, 1952: Trabert's formula and the determination of the water content in clouds. J. Meteor., 9, 167-171.

Brenguier, J.L. and H. Pawlowska, 2000: Radiative properties of boundary layer clouds: Droplet effective radius versus number concentration. $J$. Atmos. Sci., 57, 803-821.

Duynkerke, P.G., P.J. Jonker, A. Chlond, M. C. Vanzanten, J. Cuxart, P. Clark, E. Sanchez, G. Martin, G. Lenderink, and J. Teixeira, 1999: Intercomparison of three- and one-dimensional model simulations and aircraft observations of stratocumulus. Bound-Layer Meteor, 92, 453-487.

Haraoka, H., K. Tomine, T. Kawabata, K. Miyamoto, and K. Fukawarase, 1995: Some aspects on temperature, humidity and wind profiles in sea fog at Misawa city (in Japanese). Tenki, 42, 369-379.

Homma, T., K. Tamura, and T. Okita, 1962: Observations of sea fog and drizzle at Nemuro (in Japanese). J. Meteor. Res., 14, 72-79.

Inoue, K., 1992: Meteorological properties of sea fog induced by Yamase (in Japanese). Tenki, 39, 459 $-467$.

Maruyama, M. and K. Hama, 1954: On Measurement of Cloud Particle Size by means of $\mathrm{MgO}$ Smoke. J. Meteor. Soc. Japan, 32, 167-174.
Mason, S.J., 1982: The physics of radiation fog. J. Meteor. Soc. Japan, 60, 486-499.

Nicholls, S., 1984: The dynamics of stratocumulus: aircraft observations and comparisons with a mixed layer model. Quart. J. Met. Soc., 110, 783-820.

Pilié, R.J., E.J. Mack, W.C. Kocmond, W.J. Eadie, and C.W. Rogers, 1975: The life cycle of valley fog. Part II: Fog microphysics. J. Appl. Meteor., 14, 364-374.

Slingo A., S. Nicholls, and J. Schmetz, 1982: Aircraft observations of marine stratocumulus during JASIN. Quart. J. Met. Soc., 108, 833-856.

Smedman, A., H. Bergstrom, and B. Grisogono, 1997: Evolution of stable boundary layers over a cold sea. J. Geophys. Res., 102(C1), 1091-1099.

Squires, P., 1958: The microstructure and colloidal stability of warm clouds. Part I-The relation between structure and stability. Tellus, 10, 256-261.

UMIGIRI KENKYUU.GROUP, 1985; Observations of sea fog in Kushiro district (in Japanese). Tenki, $32,41-52$.

Uyeda, H. and T. Yagi, 1984: Observation of sea fogs at the urban area and the coastal suburbs in Kushiro city, Hokkaido (in Japanese). Tenki, 31, 137-145.

Warshaw, M., 1968: Cloud droplet coalescence: effects of the Davis-Sartor collision efficiency. J. Atmos. Sci., 25, 874-877.

Yanagisawa, Z., M. Ishihara, and T. Sawai, 1986: Observations of sea fog by 8.6 millimeter radar (in Japanese). Tenki, 33, 603-612. 